\title{
KARAKTERISTIK KUAT TEKAN BETON DENGAN BAHAN TAMBAHAN TEMPURUNG KENARI (CANARIUM AMBONEINSES HOCHR) DARI KABUPATEN ALOR
}

\author{
Koilal Alokabel $^{1}$, Welem Daga ${ }^{2}$
}

\begin{abstract}
Abstrak :
Kabupaten Alor merupakan satu-satunya penghasil tanaman kenari yang sangat besar di mana tanaman dimaksud tumbuh secara alami dan saat sekarang telah dibudidayakan. Bijinya digunakan sebagai bahan makanan dan tempurungnya dibuang begitu saja sehingga semakin banyak menumpuk akan merusak pemandangan sekitarnya, dengan demikian tempurungnya dapat dimanfaatkan sebagai bahan bangunan, yakni sebagai bahan tambahan. Berdasarkan hasil pengujian kuat tekan yang diperoleh yaitu perlakuan III (64 \% Kerikil + 34\% Pasir + 2\% Tempurung Kenari) dengan kuat tekan 282,83 kg/cm², perlakuan IV (63 \% Kerikil + 34\% Pasir + 3\% Tempurung Kenari) dengan kuat tekan 284,67 kg/cm² dan perlakuan V (62 \% Kerikil + 34\% Pasir + 4\% Tempurung Kenari) dengan kuat tekan 285,49 kg/cm² ini menggambarkan bahwa banyaknya tempurung kenari yang akan di campurkan maka akan menghasilkan kuat tekan yeng lebih besar. Dengan demikian tempurung kenari layak digunakan sebagai bahan tambahan campuran beton karena memberikan pengaruh yang cukup berarti terhadap kakuatan tekan beton.
\end{abstract}

Kata-kata kunci : Kerikil, Kuat Tekan Beton, Pasir, Perlakuan, Tempurung Kenari.

\section{PENDAHULUAN}

Tanaman kenari termasuk salah satu jenis tanaman asli Indonesia. Tanaman ini memiliki belasan spesies yang tersebar diseluruh wilayah nusantara antara lain meliputi, Sumatera, Jawa, Madura, Nusa Tenggara, Kalimantan, Sulawesi, Maluku dan Irian jaya. Spesies yang juga ditemukan di Filipina, Malaysia, Papua dan Australia. Tanaman kenari merupakan tanaman khas yang terdapat di Propinsi Nusa Tenggara Timur khususnya Kabupaten Alor, tanaman ini telah menjadi komoditi andalan Kabupaten Alor sehingga daerah ini dijuluki dengan nama Nusa Kenari. Kabupaten Alor merupakan satu- satunya penghasil tanaman kenari yang sangat besar di mana tanaman dimaksud tumbuh secara alami dan saat sekarang telah dibudi-dayakan.

Di dalam konstruksi beton, agregat merupakan bahan pengisi netral, dengan komposisi $70 \%$ - $75 \%$ dari masa beton. Maksud penggunaan agregat didalam adukan beton adalah menghemat penggunaan semen Portland, menghasilkan kekuatan besar pada beton, mengurangi penyusutan pada pengerasan beton, dengan gradasi agregat yang baik dapat dicapai beton padat, sifat dapat dikerjakan (workability) dapat diperiksa pada adukan beton dengan gradasi yang baik. 


\section{Tujuan Penelitian}

Tujuan dari penelitian ini adalah untuk mengetahui kuat tekan beton dengan menggunakan bahan tambahan kulit kenari dari Kabupaten Alor.

\section{Manfaat Penelitian}

Manfaat dari penelitian ini adalah manfaat untuk dapat memberikan kontribusi kepada masyarakat dan pemerintah Kabupaten Alor, serta dapat dijadikan bahan informasi bagi penelitian dan pengembangan lebih lanjut dibidang teknologi bahan bangunan.

\section{TINJAUAN PUSTAKA}

Beton
Beton adalah campuran antara semen Portland atau semen hidrolik, agregat halus, agregat kasar dan air dengan atau tanpa bahan campuran, bahan tambahan membentuk masa padat. Sesuai dengan PBI 1971, beton adalah suatu bahan konstruksi yang mempunyai sifat kekuatan tekan yang kas yaitu apabila diperiksa dengan sejumlah besar benda uji nilainya akan menyebar sekitar suatu nilai rata-rata tertentu.

\section{Kuat tekan beton}

Kuat tekan beton adalah kemampuan beton menerima beban persatuan luas yang menyebabkan benda uji hancur bila telah dibebani gaya tekan maksimum yang dihasilkan oleh mesin tekan uji.

Tabel 1. Kelas dan Mutu Beton

\begin{tabular}{|c|c|c|c|c|c|c|}
\hline \multirow{2}{*}{ Kls } & \multirow{2}{*}{ Mutu } & \multirow{2}{*}{$\begin{array}{c}\sigma^{\prime} b k \\
\left(\mathrm{~kg} / \mathrm{cm}^{2}\right)\end{array}$} & \multirow{2}{*}{$\begin{array}{c}\sigma^{\prime} b m \\
\text { Dgn. } \mathrm{S}=46 \\
\left(\mathrm{~kg} / \mathrm{cm}^{2}\right)\end{array}$} & \multirow{2}{*}{ Tujuan } & \multicolumn{2}{|c|}{$\begin{array}{l}\text { Pengawasan } \\
\text { terhadap }\end{array}$} \\
\hline & & & & & $\begin{array}{l}\text { Mutu } \\
\text { agregat }\end{array}$ & $\begin{array}{l}\text { Kuat } \\
\text { tekan }\end{array}$ \\
\hline I & $\mathrm{B}_{0}$ & - & - & $\begin{array}{l}\text { Non } \\
\text { truktur }\end{array}$ & Ringan & Tanpa \\
\hline \multirow{4}{*}{ II } & $\mathrm{B}_{1}$ & - & - & Strukturil & Sedang & Tanpa \\
\hline & K 125 & K 125 & 200 & Strukturil & Ketat & Kontinue \\
\hline & K175 & K 175 & 250 & Strukturil & Ketat & Kontinue \\
\hline & K225 & K 225 & 300 & Strukturil & Ketat & Kontinue \\
\hline III & $K>225$ & $>250$ & $>300$ & Strukturil & Ketat & Kontinue \\
\hline
\end{tabular}

Sumber : Peraturan Beton Bertulang Indonesia, 1971

\section{Kenari (Canarium Amboinenses Hochr)}

Kulit kenari memiliki permukaan yang sangat keras sehingga, tidak mudah untuk ditembus air, tidak hancur oleh pengaruh suhu, tidak berkarat bila disimpan lama, dan tidak berpori-pori.
Tabel 2. Jumlah tegakan pohon kenari di Kabupaten Alor

\begin{tabular}{|c|c|c|}
\hline No & Kecamatan & $\begin{array}{c}\text { Jumlah Tegakan } \\
\text { (pohon) }\end{array}$ \\
\hline 1 & Alor Barat Daya & 36.367 \\
\hline 2 & Alor Timur & 27.893 \\
\hline 3 & Pantar & 21.848 \\
\hline 4 & Alor Barat Laut & 6.373 \\
\hline \multicolumn{2}{|c|}{ Jumlah } & 92.488 \\
\hline
\end{tabular}

Sumber: Dinas Kehutanan Kab. Alor (2005) 
Tabel 3. Perkembangan Produksi Rata-Rata Buah Kenari Perpohon

\begin{tabular}{|c|c|c|}
\hline No & $\begin{array}{c}\text { Umur } \\
\text { (tahun) }\end{array}$ & $\begin{array}{c}\text { Berat rata-rata kulit kenari } \\
\text { perpohon }(\mathrm{kg})\end{array}$ \\
\hline 1 & 30 & 68,5 \\
\hline 2 & 35 & 92 \\
\hline 3 & 40 & 123,5 \\
\hline 4 & 45 & 135,8 \\
\hline 5 & 50 & 149,3 \\
\hline
\end{tabular}

Sumber : Harsono Ahmadi Koda. (Tahun 2004)

\section{METODOLOGI}

Benda uji untuk pengujian kuat tekan beton berupa kubus sebanyak 25 benda uji dengan ukuran $15 \times 15 \times 15 \mathrm{~cm}$. Pengujian kualitas setelah beton dalam penelitian ini dilakukan setelah benda uji berumur 28 hari.

Pembuatan benda uji dibedakan menjadi 5 perlakuan dan masing-masing perlakuan dibuat sebanyak 5 benda uji. Perbedaannya adalah pada perbandingan campuran. Untuk lebih jelasnya dapat dilihat pada tabel berikut.

Tabel 4. Prosentase Kulit Kenari Terhadap Agregat Kasar.

\begin{tabular}{|c|c|c|c|c|}
\hline No & Perlakuan & $\begin{array}{c}\text { Kuat Tekan } \\
\text { Karakteristik }\end{array}$ & $\begin{array}{c}\text { Kulit } \\
\text { Kenari (\%) }\end{array}$ & Jumlah \\
\hline 1 & I & K 175 & 0 & 5 \\
\hline 2 & II & K 175 & 1 & 5 \\
\hline 3 & III & K 175 & 2 & 5 \\
\hline 4 & IV & K 175 & 3 & 5 \\
\hline 5 & V & K 175 & 4 & 5 \\
\hline
\end{tabular}

Sumber : Penulis 2016
Tahapan penelitian ini dapat dijelaskan dalam bagan alir ini,

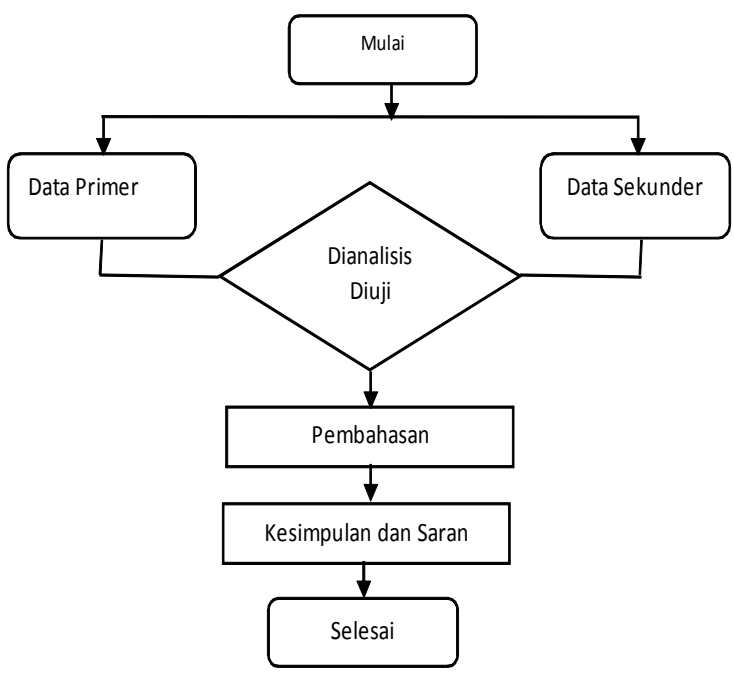

Gambar 1. Bagan alir penelitian

\section{HASIL DAN PEMBAHASAN}

\section{A. Pengujian Bahan Material Beton}

\section{Agregat Halus}

Banyaknya penggunaan agregat halus untuk proses pengujian serta prosentase yang lolos untuk setiap saringan dapat dilihat pada tabel 5 berikut ini,

Tabel 5. Hasil Analisis Saringan Agregat Halus (Pasir Takari)

Berat Awal $(W)=925$ gram

\begin{tabular}{|c|c|c|c|c|}
\hline \multicolumn{2}{|c|}{ No. Saringan } & \multirow{2}{*}{$\begin{array}{l}\text { Berat } \\
\text { tertahan } \\
\text { (gram) }\end{array}$} & \multirow{2}{*}{$\begin{array}{c}\% \\
\text { Tertahan }\end{array}$} & \multirow{2}{*}{$\begin{array}{c}\% \\
\text { Lolos }\end{array}$} \\
\hline ASTM & $(\mathrm{mm})$ & & & \\
\hline $2^{\prime \prime}$ & 63.0 & 0 & 0,00 & 100 \\
\hline 1I” & 37.5 & 0 & 0,00 & 100 \\
\hline$---"$ & 19.0 & 0 & 0,00 & 100 \\
\hline $3 / 8 "$ & 9.51 & 0 & 0,00 & 100 \\
\hline Nmr 4 & 4.75 & 0 & 0,00 & 100 \\
\hline Nmr 8 & 2.36 & 147 & 15,89 & 84,11 \\
\hline Nmr 16 & 1.18 & 514 & 55,57 & 44,43 \\
\hline Nmr 30 & 0.600 & 725 & 78,38 & 21,62 \\
\hline Nmr 50 & 0.300 & 780 & 84,32 & 15,68 \\
\hline Nmr 100 & 0.150 & 869 & 93,95 & 6,05 \\
\hline Nmr 200 & 0.075 & 890 & 96,22 & 3,78 \\
\hline
\end{tabular}

Sumber : Data Hasil Pengujian Laboratorium, 2016 
Berdasarkan hasil analisis ayak agregat halus terhadap pasir Takari dari tabel di atas, menunjukan bahwa ternyata pasir Takari memenuhi syarat sebagai bahan material beton karena memenuhi batas dalam gradasi pasir untuk daerah pasir zone 2 (dua) dimana prosentase lolos untuk saringan nomor 200 harus $>0 \%$.

\section{Agregat Kasar}

Banyaknya penggunaan material agregat kasar (kerikil) untuk proses pengujian serta prosentase yang lolos untuk setiap nomor saringan dapat dilihat pada tabel dibawah ini,

Tabel 6. Hasil Analisis Saringan Agregat Kasar (Kerikil)

\begin{tabular}{|c|c|c|c|c|}
\hline \multicolumn{5}{|c|}{ Berat Awal $(W)=3275$ gram } \\
\hline \multicolumn{2}{|c|}{ No. Saringan } & \multirow[b]{2}{*}{$\begin{array}{l}\text { Berat } \\
\text { tertahan }\end{array}$} & \multirow[b]{2}{*}{$\begin{array}{c}\% \\
\text { Tertahan }\end{array}$} & \multirow{2}{*}{$\begin{array}{c}\% \\
\text { Lolos } \\
\text { seluruh } \\
\text { contoh }\end{array}$} \\
\hline ASTM & $(\mathrm{mm})$ & & & \\
\hline $2 "$ & 63.0 & 0 & 0,00 & 100 \\
\hline $1 \mathrm{II}$ & 37.5 & 0 & 0,00 & 100 \\
\hline$--"$ & 19.0 & 1381 & 42,17 & 57,83 \\
\hline $3 / 8 "$ & 9.51 & 2925 & 89,31 & 10,69 \\
\hline Nmr 4 & 4.75 & 3213 & 98,11 & 1,89 \\
\hline Nmr 8 & 2.36 & 3268 & 99,79 & 0,21 \\
\hline Nmr 16 & 1.18 & 0 & 0,00 & 0,00 \\
\hline Nmr 30 & 0.600 & 0 & 0,00 & 0,00 \\
\hline Nmr 50 & 0.300 & 0 & 0,00 & 0,00 \\
\hline Nmr 100 & 0.150 & 0 & 0,00 & 0,00 \\
\hline Nmr 200 & 0.075 & 0 & 0,00 & 0,00 \\
\hline
\end{tabular}

Sumber : Data Hasil Pengujian Laboratorium, 2016

Berdasarkan hasil analisis ayakan agregat kasar yang diperoleh dari tabel diatas, dapat dilihat bahwa ternyata agregat kasar memenuhi syarat sebagai material beton karena memenuhi batas dalam gradasi kerikil untuk besar ukuran butiran maksimum $38 \mathrm{~mm}$ yaitu prosentase lolos saringan 2" sebesar $100 \%$ dan saringan 3/4" sebesar $100 \%$ dan memenuhi syarat daerah A.

\section{Tempurung Kenari}

Banyaknya penggunaan material tempurung kenari untuk proses pengujian serta prosentase yang lolos untuk setiap nomor saringan dapat dilihat pada tabel dibawah ini,

Tabel 7. Hasil Analisis Saringan Tempurung Kenari.

Berat Awal $(W)=1029$ gram

\begin{tabular}{|c|c|c|c|c|}
\hline \multicolumn{2}{|c|}{ No. Saringan } & \multirow{2}{*}{$\begin{array}{c}\text { No. } \\
\text { ASTM }\end{array}$} & $\begin{array}{c}\text { \% } \\
\text { (mm) }\end{array}$ & $\begin{array}{c}\% \\
\text { Saringan } \\
\text { Tolos } \\
\text { soluruh } \\
\text { contoh }\end{array}$ \\
\hline 2" & 63.0 & 0 & 0 & 100 \\
\hline 1 1I” & 37.5 & 0 & 0 & 100 \\
\hline$--"$ & 19.0 & 0 & 0 & 100 \\
\hline ” & 9.51 & 1020 & 99,13 & 0,87 \\
\hline Nmr 4 & 4.75 & 1028 & 99,90 & 0,10 \\
\hline Nmr 8 & 2.36 & 0 & 100 & 0,00 \\
\hline Nmr 16 & 1.18 & 0 & 0,00 & 0,00 \\
\hline Nmr 30 & 0.600 & 0 & 0,00 & 0,00 \\
\hline Nmr 50 & 0.300 & 0 & 0,00 & 0,00 \\
\hline Nmr 100 & 0.150 & 0 & 0,00 & 0,00 \\
\hline Nmr 200 & 0.075 & 0 & 0,00 & 0,00 \\
\hline
\end{tabular}

Sumber : Data Hasil Pengujian Laboratorium, 2016

Berdasarkan hasil analisis ayakan agregat yang diperoleh dari tabel diatas, dapat dilihat bahwa ternyata tempurung kenari memenuhi syarat sebagai bahan tambahan beton karena memenuhi batas dalam gradasi untuk besar ukuran butiran maksimum $38 \mathrm{~mm}$ yaitu prosentase lolos untuk saringan 2" sebesar 100 $\%$ dan saringan $3 / 4 "$ sebesar $100 \%$ berat dan memenuhi syarat daerah A.

\section{B. Hasil Analisa Berat Jenis Agregat}

\section{Agregat Halus}

Tabel 8. Hasil Analisis Berat Jenis Pasir Takari $\begin{array}{cccc}\text { Uraian } & \text { I } & \text { II } & \text { Satuan } \\ \text { Berat benda uji } & 500 & 500 & \text { Gram }\end{array}$ (SSD)

Berat benda uji 484,17 483,71 Gram kering oven (BK)

Berat piknometer $+\quad 686,68 \quad 678,65 \quad$ Gram air (BA) 


\section{JUTEKS Jurnal Teknik Sipil Volume 2 Nomor 1 April 2017}

\begin{tabular}{|c|c|c|}
\hline $\begin{array}{l}\text { Berat piknometer + } \\
\text { air + benda uji (BT) }\end{array}$ & 996,18 & 989,15 \\
\hline Berat Jenis & 2,54 & 2,55 \\
\hline & \multicolumn{2}{|c|}{2,545} \\
\hline$\underset{S S D}{\text { Berat Jenis (SSD) }}$ & \multirow{2}{*}{2,62} & 2,64 \\
\hline & & 2,630 \\
\hline \multirow{2}{*}{$\begin{array}{l}\text { Berat Jenis } \\
\text { (Apperent) }\end{array}$} & 2,77 & 2,79 \\
\hline & \multicolumn{2}{|c|}{2,780} \\
\hline Penyerapan air & 3,27 & 3,37 \\
\hline$S S D-B K-\times 100 \%$ & \multicolumn{2}{|c|}{3,345} \\
\hline
\end{tabular}

Sumber : Data Hasil Pengujian Laboratorium, 2016

Berdasarkan hasil pengujian Berat Jenis terhadap agregat halus (pasir Takari) diperoleh Berat Jenis (SSD) yaitu 2,63. nilai ini akan digunakan untuk merancang campuran uji (Mix Design) yakni menghitung berat jenis Relative Density (RD) untuk mengetahui volume beton basah untuk kebutuhan bahan, sedangkan ${ }^{\bar{B}}$ penyerapan sebesar 3,345 digunakan untuk menghitung koreksi kebutuhan air dalam rancangan campuran yang akan digunakan untuk mengetahui tiap $\mathrm{m}^{3}$.

\section{Agregat Kasar}

\subsection{Kerikil}

Tabel 9. Hasil Analisis Berat Jenis Kerikil

\begin{tabular}{|l|c|c|}
\hline \multicolumn{1}{|c|}{ Uraian } & I & Satuan \\
\hline Berat benda uji (SSD) & Gram \\
\hline $\begin{array}{l}\text { Berat kering permukaan } \\
\text { jenuh (BJ) }\end{array}$ & 2780 & Gram \\
\hline $\begin{array}{l}\text { Berat benda uji di dalam } \\
\text { air (BA) }\end{array}$ & 1725 & Gram \\
\hline $\begin{array}{l}\text { Berat benda uji kering } \\
\text { oven (BK) }\end{array}$ & 2730 & Gram \\
\hline $\begin{array}{l}\text { Berat Jenis (BULK) } \\
\text { BK }\end{array}$ & 2,59 & \\
\hline \begin{tabular}{l} 
BA SSD - BT \\
\hline
\end{tabular} & & \\
\hline
\end{tabular}

\begin{tabular}{|l|l|l|}
\hline $\begin{array}{l}\text { Berat Jenis (SSD) } \\
\frac{S S D}{B A+S S D-B T}\end{array}$ & 2,64 & \\
\hline $\begin{array}{l}\text { Berat Jenis (Apperent) } \\
\frac{\mathrm{BK}}{\mathrm{BA}+\mathrm{BK}-\mathrm{BT}}\end{array}$ & 2,77 & \\
\hline $\begin{array}{l}\text { Penyerapan air } \\
\frac{S S D-B K}{B K} \times 100 \%\end{array}$ & 1,83 & \\
\hline
\end{tabular}

Sumber : Data Hasil Pengujian Laboratorium, 2016

\subsection{Tempurung Kenari}

Tabel 10. Hasil Analisis Berat Jenis Tempurung Kenari

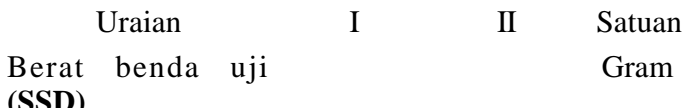

Berat kering

$1378 \quad 1310 \quad$ Gram

permukaan jenuh

(BJ)

\begin{tabular}{|c|c|c|c|}
\hline $\begin{array}{l}\text { Berat benda uji di } \\
\text { dalam air (BA) } \\
\text { BK }\end{array}$ & 365 & 350 & Gram \\
\hline $\begin{array}{l}\text { Beserddiji } \\
\text { kering oven (BK) }\end{array}$ & 1192 & 1133 & Gram \\
\hline $\begin{array}{l}\text { Berat Jenis } \\
\text { (BULK) }\end{array}$ & 1,18 & 1,18 & \\
\hline & \multicolumn{2}{|c|}{1,18} & \\
\hline $\begin{array}{l}\text { Berat Jenis } \\
\text { (SSD) }\end{array}$ & 1,36 & 1,36 & \\
\hline \begin{tabular}{c}
\multicolumn{3}{c}{$S S D$} \\
$B A+S S D-B T$
\end{tabular} & \multicolumn{2}{|c|}{1,36} & \\
\hline $\begin{array}{l}\text { Berat Jenis } \\
\text { (Apperent) }\end{array}$ & 1,44 & 1,45 & \\
\hline $\begin{array}{c}\text { BK } \\
\mathrm{BA}+\mathrm{BK}-\mathrm{BT}\end{array}$ & \multicolumn{3}{|c|}{1,44} \\
\hline Penyerapan air & 15,60 , & 15,62 & \\
\hline$\frac{S S D-B K}{B K} \times 100 \%$ & & & \\
\hline
\end{tabular}

Sumber : Data Hasil Pengujian Laboratorium, 2016 
Alokabel ${ }^{1}$, Daga ${ }^{2}$ Karakteristik Kuat Tekan Beton Dengan Bahan Tambahan Tempurung Kenari (Canarium Amboneinses Hochr) Dari Kabupaten Alor

C. Perhitungan Rancangan Campuran (Mix Design).

a. Perlakuan I ( 0 \% Tempurung Kenari).

Tabel 11. Spesifikasi Gradasi Agregat Gabungan

\begin{tabular}{|c|c|c|c|c|c|c|}
\hline \multirow{2}{*}{$\begin{array}{c}\text { Ukuran } \\
\text { Saringan }\end{array}$} & \multicolumn{2}{|c|}{ Kerikil 66 \% } & \multicolumn{2}{|c|}{ Pasir $34 \%$} & \multirow[b]{2}{*}{ Hasil } & \multirow[b]{2}{*}{ Spec } \\
\hline & $\begin{array}{l}\text { Komulatif } \\
\text { lolos }\end{array}$ & \% Lolos & $\begin{array}{l}\text { Komulatif } \\
\text { lolos }\end{array}$ & $\begin{array}{c}\% \\
\text { Lolos }\end{array}$ & & \\
\hline $2 "$ & 100 & 66 & 100 & 34 & 100 & 100 \\
\hline $1 \mathrm{I} ”$ & 100 & 66 & 100 & 34 & 100 & 100 \\
\hline --” & 57,83 & 38,17 & 100 & 34 & 72,17 & 50-75 \\
\hline$"$ & 10,69 & 7,06 & 100 & 34 & 41,06 & $35-60$ \\
\hline No. 4 & 1,89 & 1,25 & 100 & 34 & 35,25 & $24-46$ \\
\hline No. 8 & 0,21 & 0,14 & 84,11 & 28,60 & 28,74 & $17-36$ \\
\hline No. 16 & - & - & 44,43 & 15,11 & 15,11 & $12-30$ \\
\hline No. 30 & - & - & 21,62 & 7,35 & 7,35 & $6-23$ \\
\hline No. 50 & - & - & 15,68 & 5,33 & 5,33 & 4-14 \\
\hline No. 100 & - & - & 6,05 & 2,06 & 2,06 & $2-6$ \\
\hline No. 200 & - & - & 3,78 & 1,28 & 1,28 & 0 \\
\hline
\end{tabular}

Sumber : Data Hasil Pengujian Laboratorium, 20/816

\section{b. Perlakuan II ( 1 \% Tempurumg Kenari).}

Tabel 12. Hasil Analisis Berat Jenis Tempurung Kenari

\begin{tabular}{|c|c|c|c|c|c|c|c|c|}
\hline \multirow{2}{*}{$\begin{array}{c}\text { Ukuran } \\
\text { Saringan }\end{array}$} & \multicolumn{2}{|c|}{ Kerikil 65 \% } & \multicolumn{2}{|c|}{ Kanari 1\% } & \multicolumn{2}{|c|}{ Pasir 34\% } & \multirow{2}{*}{ Hasil } & \multirow{2}{*}{ Spec } \\
\cline { 2 - 8 } & $\begin{array}{c}\text { Komulatif } \\
\text { lolos }\end{array}$ & $\begin{array}{c}\% \\
\text { Lolos }\end{array}$ & $\begin{array}{c}\text { Komulatif } \\
\text { lolos }\end{array}$ & $\begin{array}{c}\% \\
\text { Lolos }\end{array}$ & $\begin{array}{c}\text { Komulatif } \\
\text { lolos }\end{array}$ & $\begin{array}{c}\% \\
\text { Lolos }\end{array}$ & \\
\hline 2" & 100 & 65 & 100 & 1 & 100 & 34 & 100 & 100 \\
\hline 1 I " & 57,83 & 37.59 & 100 & 1 & 100 & 34 & 100 & 100 \\
\hline$--"$ & 10,69 & 6,95 & 100 & 1 & 100 & 34 & 72,17 & $50-75$ \\
\hline " & 1,89 & 1,23 & 100 & 1 & 100 & 34 & 41,06 & $35-60$ \\
\hline No. 4 & 0,21 & 0,14 & 0,87 & 0.009 & 100 & 34 & 35,25 & $24-46$ \\
\hline No. 8 & - & - & 0,10 & 0.001 & 84,11 & 28,60 & 28,74 & $17-36$ \\
\hline No. 16 & - & - & - & - & 44,43 & 15,11 & 15,11 & $12-30$ \\
\hline No. 30 & - & - & - & - & 21,62 & 7,35 & 7,35 & $6-23$ \\
\hline No. 50 & - & - & - & - & 15,68 & 5,33 & 5,33 & $4-14$ \\
\hline No. 100 & - & - & - & - & 6,05 & 2,06 & 2,06 & $2-6$ \\
\hline No. 200 & & & & & 3,78 & 1,28 & 1,28 & 0 \\
\hline
\end{tabular}

Sumber : Data Hasil Pengujian Laboratorium, 2016 


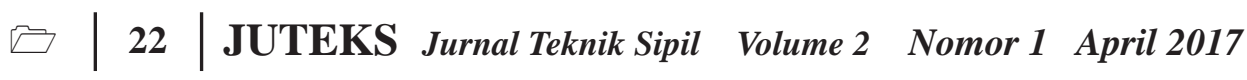

c. Perlakuan III ( 2 \% Tempurung Kenari).

Tabel 13. Hasil Analisis Berat Jenis Tempurung Kenari

\begin{tabular}{|c|c|c|c|c|c|c|c|c|}
\hline \multirow{2}{*}{ Saringan } & \multicolumn{2}{|c|}{ Kerikil 64\% } & \multicolumn{2}{|c|}{ Kanari 2 \% } & \multicolumn{2}{|c|}{ Pasir 34 \% } & \multirow{2}{*}{ Hasil } & Spec \\
\cline { 2 - 8 } & $\begin{array}{c}\text { Komulatif } \\
\text { lolos }\end{array}$ & $\begin{array}{c}\% \\
\text { Lolos }\end{array}$ & $\begin{array}{c}\text { Komulatif } \\
\text { lolos }\end{array}$ & $\begin{array}{c}\% \\
\text { Lolos }\end{array}$ & $\begin{array}{c}\text { Komulatif } \\
\text { lolos }\end{array}$ & $\begin{array}{c}\% \\
\text { Lolos }\end{array}$ & & \\
\hline 2" & 100 & 64 & 100 & 2 & 100 & 34 & 100 & 100 \\
\hline 1 I " & 100 & 64 & 100 & 2 & 100 & 34 & 100 & 100 \\
\hline$--"$ & 57,83 & 37,01 & 100 & 2 & 100 & 34 & 73,01 & $50-75$ \\
\hline 3/8 " & 10,69 & 6,84 & 0,87 & 0,02 & 100 & 34 & 40,86 & $35-60$ \\
\hline No. 4 & 1,89 & 0,21 & 0,10 & 0,002 & 100 & 34 & 35,21 & $24-46$ \\
\hline No. 8 & 0,21 & 0,31 & - & - & 84,11 & 28,60 & 28,73 & $17-36$ \\
\hline No. 16 & - & & - & - & 44,43 & 15,11 & 15,10 & $12-30$ \\
\hline No. 30 & - & - & - & - & 21,62 & 7,35 & 7,35 & $6-23$ \\
\hline No. 50 & - & - & - & - & 15,68 & 5,33 & 5,33 & $4-14$ \\
\hline No. 100 & - & - & - & - & 6,05 & 2,06 & 2,06 & $2-5$ \\
\hline No. 200 & - & - & - & - & 3,78 & 1,28 & - & 0 \\
\hline
\end{tabular}

Sumber : Data Hasil Pengujian Laboratorium, 2016

\section{d. Perlakuan IV ( 3 \% Tempurumg Kenari).}

Tabel 14. Hasil Analisis Berat Jenis Tempurung Kenari

\begin{tabular}{|c|c|c|c|c|c|c|c|c|}
\hline \multirow{2}{*}{ Saringan } & \multicolumn{2}{|c|}{ Kerikil 64\% } & \multicolumn{2}{|c|}{ Kanari 2 \% } & \multicolumn{2}{|c|}{ Pasir 34 \% } & \multirow{2}{*}{ Hasil } & Spec \\
\cline { 2 - 8 } & $\begin{array}{c}\text { Komulatif } \\
\text { lolos }\end{array}$ & $\begin{array}{c}\% \\
\text { Lolos }\end{array}$ & $\begin{array}{c}\text { Komulatif } \\
\text { lolos }\end{array}$ & $\begin{array}{c}\% \\
\text { Lolos }\end{array}$ & $\begin{array}{c}\text { Komulatif } \\
\text { lolos }\end{array}$ & $\begin{array}{c}\% \\
\text { Lolos }\end{array}$ & & \\
\hline 2" & 100 & 62 & 100 & 4 & 100 & 34 & 100 & 100 \\
\hline 1 I " & 100 & 62 & 100 & 4 & 100 & 34 & 100 & 100 \\
\hline$--"$ & 57,83 & 36,43 & 100 & 4 & 100 & 34 & 73,43 & $50-75$ \\
\hline 3/8 " & 10,69 & 6,73 & 0,87 & 0,03 & 100 & 34 & 40,76 & $35-60$ \\
\hline No. 4 & 1,89 & 1,19 & 0,10 & 0,004 & 100 & 34 & 35,19 & $24-46$ \\
\hline No. 8 & 0,21 & 0,13 & - & - & 84,11 & 28,60 & 28,73 & $17-36$ \\
\hline No. 16 & - & - & - & - & 44,43 & 15,11 & 15,10 & $12-30$ \\
\hline No. 30 & - & - & - & - & 21,62 & 7,35 & 7,35 & $6-23$ \\
\hline No. 50 & - & - & - & - & 15,68 & 5,33 & 5,33 & $4-14$ \\
\hline No. 100 & - & - & - & - & 6,05 & 2,06 & 2,06 & $2-5$ \\
\hline No. 200 & - & - & - & - & 3,78 & 1,28 & 1,87 & 0 \\
\hline
\end{tabular}

Sumber : Data Hasil Pengujian Laboratorium, 2016 


\section{e. Perlakuan V ( 4 \% Tempurumg Kenari).}

Tabel 15. Hasil Analisis Berat Jenis Tempurung Kenari

\begin{tabular}{|c|c|c|c|c|c|c|c|c|}
\hline \multirow{2}{*}{ Saringan } & \multicolumn{2}{|c|}{ Kerikil 64\% } & \multicolumn{2}{|c|}{ Kanari 2 \% } & \multicolumn{2}{|c|}{ Pasir 34 \% } & \multirow{2}{*}{ Hasil } & Spec \\
\cline { 2 - 8 } & $\begin{array}{c}\text { Komulatif } \\
\text { lolos }\end{array}$ & $\begin{array}{c}\% \\
\text { Lolos }\end{array}$ & $\begin{array}{c}\text { Komulatif } \\
\text { lolos }\end{array}$ & $\begin{array}{c}\% \\
\text { Lolos }\end{array}$ & $\begin{array}{c}\text { Komulatif } \\
\text { lolos }\end{array}$ & $\begin{array}{c}\% \\
\text { Lolos }\end{array}$ & & \\
\hline 2" & 100 & 62 & 100 & 4 & 100 & 34 & 100 & 100 \\
\hline 1 I " & 100 & 62 & 100 & 4 & 100 & 34 & 100 & 100 \\
\hline$--"$ & 57,83 & 36,43 & 100 & 4 & 100 & 34 & 73,43 & $50-75$ \\
\hline 3/8" & 10,69 & 6,73 & 0,87 & 0,03 & 100 & 34 & 40,76 & $35-60$ \\
\hline No. 4 & 1,89 & 1,19 & 0,10 & 0,004 & 100 & 34 & 35,19 & $24-46$ \\
\hline No. 8 & 0,21 & 0,13 & - & - & 84,11 & 28,60 & 28,73 & $17-36$ \\
\hline No. 16 & - & - & - & - & 44,43 & 15,11 & 15,10 & $12-30$ \\
\hline No. 30 & - & - & - & - & 21,62 & 7,35 & 7,35 & $6-23$ \\
\hline No. 50 & - & - & - & - & 15,68 & 5,33 & 5,33 & $4-14$ \\
\hline No. 100 & - & - & - & - & 6,05 & 2,06 & 2,06 & $2-5$ \\
\hline No. 200 & - & - & - & - & 3,78 & 1,28 & 1,87 & 0 \\
\hline
\end{tabular}

Sumber : Data Hasil Pengujian Laboratorium, 2016

\section{Pengujian Kuat Tekan Beton}

Hasil pengujian kuat tekan beton setelah berumur 28 hari untuk tiap perlakuan dapat dilihat pada tabel dibawah ini :

Tabel 16. Hasil Pengujian Kuat Tekan Kubus Beton

\begin{tabular}{|c|c|c|c|c|c|c|c|c|c|c|}
\hline \multirow{2}{*}{ No } & \multicolumn{2}{|c|}{ Tanggal } & \multirow{2}{*}{ Slump } & \multirow{2}{*}{$\begin{array}{l}\text { Umur } \\
\text { Hari }\end{array}$} & \multirow{2}{*}{$\begin{array}{c}\text { Berat } \\
\text { (gr) }\end{array}$} & \multirow{2}{*}{$\begin{array}{c}\text { Luas } \\
\text { Penampang }\end{array}$} & \multirow{2}{*}{$\begin{array}{l}\text { Berat } \\
\text { Isi }\end{array}$} & \multirow{2}{*}{$\begin{array}{c}\text { Beban } \\
\max \end{array}$} & \multicolumn{2}{|c|}{$\begin{array}{c}\text { Kuat tekan } \\
\left(\mathrm{Kg} / \mathrm{cm}^{2}\right)\end{array}$} \\
\hline & Cor & Uji & & & & & & & Aktual & $\begin{array}{c}28 \\
\text { hari }\end{array}$ \\
\hline \multicolumn{11}{|c|}{ PERLAKUAN I } \\
\hline 1 & $19 / 07$ & $17 / 08$ & 10 & 28 & 8580 & 225 & 2,54 & 63240 & 281 & 281 \\
\hline 2 & $19 / 07$ & $17 / 08$ & 10 & 28 & 8536 & 225 & 2,53 & 61200 & 272 & 272 \\
\hline 3 & $19 / 07$ & $17 / 08$ & 10 & 28 & 8627 & 225 & 2,56 & 62220 & 276,5 & 276,5 \\
\hline 4 & $19 / 07$ & $17 / 08$ & 10 & 28 & 8663 & 225 & 2,57 & 64260 & 285,6 & 285,6 \\
\hline 5 & $19 / 07$ & $17 / 08$ & 10 & 28 & 8391 & 225 & 2,49 & 78540 & 349,1 & 349,1 \\
\hline \multicolumn{10}{|c|}{ Nilai Rata-Rata } & 292,84 \\
\hline \multicolumn{11}{|c|}{ PERLAKUAN II } \\
\hline 1 & $19 / 07$ & $17 / 08$ & 14 & 28 & 8424 & 225 & 2,50 & 57120 & 253,9 & 253,9 \\
\hline 2 & $19 / 07$ & $17 / 08$ & 14 & 28 & 8197 & 225 & 2,43 & 59160 & 262,93 & 262,93 \\
\hline 3 & $19 / 07$ & $17 / 08$ & 14 & 28 & 8176 & 225 & 2,42 & 71400 & 317,33 & 317,33 \\
\hline 4 & $19 / 07$ & $17 / 08$ & 14 & 28 & 8810 & 225 & 2,61 & 61200 & 272 & 272 \\
\hline
\end{tabular}


24 JUTEKS Jurnal Teknik Sipil Volume 2 Nomor 1 April 2017

\begin{tabular}{|c|c|c|c|c|c|c|c|c|c|c|}
\hline 5 & $19 / 07$ & $17 / 08$ & 14 & 28 & 8550 & 225 & 2,53 & 68340 & 303,73 & 303,73 \\
\hline & \multicolumn{9}{|c|}{ Nilai Rata-Rata } & 282 \\
\hline \multicolumn{11}{|c|}{ PERLAKUAN III } \\
\hline 1 & $20 / 07$ & $18 / 08$ & 15 & 28 & 8503 & 225 & 2,52 & 63240 & 281 & 281 \\
\hline 2 & $20 / 07$ & $18 / 08$ & 15 & 28 & 8700 & 225 & 2,58 & 63240 & 281 & 281 \\
\hline 3 & $20 / 07$ & $18 / 08$ & 15 & 28 & 8450 & 225 & 2,50 & 63240 & 281 & 281 \\
\hline 4 & $20 / 07$ & $18 / 08$ & 15 & 28 & 8400 & 225 & 2,49 & 65280 & 290,13 & 290,13 \\
\hline 5 & $20 / 07$ & $18 / 08$ & 15 & 28 & 8515 & 225 & 2,52 & 63240 & 281 & 281 \\
\hline \multicolumn{10}{|c|}{ Nilai Rata-Rata } & 282,83 \\
\hline \multicolumn{11}{|c|}{ PERLAKUAN IV } \\
\hline 1 & $20 / 07$ & $18 / 08$ & 14,5 & 28 & 8302 & 225 & 2,46 & 64260 & 285,6 & 285,6 \\
\hline 2 & $20 / 07$ & $18 / 08$ & 14,5 & 28 & 8279 & 225 & 2,45 & 65280 & 290,13 & 290,13 \\
\hline 3 & $20 / 07$ & $18 / 08$ & 14,5 & 28 & 8419 & 225 & 2,49 & 63240 & 281 & 281 \\
\hline 4 & $20 / 07$ & $18 / 08$ & 14,5 & 28 & 8405 & 225 & 2,49 & 64260 & 285,6 & 285,6 \\
\hline 5 & $20 / 07$ & $18 / 08$ & 14,5 & 28 & 8470 & 225 & 2,51 & 63240 & 281 & 281 \\
\hline \multicolumn{10}{|c|}{ Nilai Rata-Rata } & 284,67 \\
\hline \multicolumn{11}{|c|}{ PERLAKUAN V } \\
\hline 1 & $21 / 07$ & $19 / 08$ & 14 & 28 & 8652 & 225 & 2,56 & 63240 & 281 & 281 \\
\hline 2 & $21 / 07$ & $19 / 08$ & 14 & 28 & 8365 & 225 & 2,48 & 63240 & 281 & 281 \\
\hline 3 & $21 / 07$ & $19 / 08$ & 14 & 28 & 8423 & 225 & 2,50 & 66300 & 294,67 & 294,67 \\
\hline 4 & $21 / 07$ & 19/08 & 14 & 28 & 8294 & 225 & 2,46 & 63240 & 281 & 281 \\
\hline 5 & $21 / 07$ & $19 / 08$ & 14 & 28 & 8403 & 225 & 2,49 & 65200 & 289,78 & 289,78 \\
\hline \multicolumn{10}{|c|}{ Nilai Rata-Rata } & 285,49 \\
\hline
\end{tabular}

Sumber : Data Hasil Pengujian Laboratorium, 2016

Dari hasil tersebut menunjukan bahwa penambahan tempurung kenari mempunyai pengaruh yang cukup berarti terhadap kuat tekan beton percobaan yang diuji. Dari tabel 16, menunjukan bahwa rata-rata besar nilai kekuatan beton yang terbesar adalah 285,49kg/ $\mathrm{cm}^{2}$ (perlakuan IV) dan yang terkecil adalah $282 \mathrm{~kg} / \mathrm{cm}^{2}$ (perlakuan II). Dari data tersebut dapat disimpulkan bahwa prosentase penambahan tempurung kenari memberikan pengaruh yang besar terhadap kekuatan beton percobaan, yaitu semakin banyak penambahan posentase tempurung kenari maka semakin besar nilai kuat tekan beton yang dihasilkan.

\section{KESIMPULAN}

Berdasarkan hasil penelitian yang telah dilaksanakan, maka dapat disimpulkan sebagai berikut :

1.Kuat tekan yang dihasilkan untuk tiap perlakuan, sangat berbeda. Kuat tekan beton yang dihasilkan adalah:

a.Perlakuan $\mathrm{I}=240,539 \mathrm{~kg} / \mathrm{cm}^{2}$, adalah sebagai pembanding, Perlakuan II = 237,344 kg/cm², Perlakuan III = 276, 134 $\mathrm{kg} / \mathrm{cm}^{2}$, Perlakuan IV $=278,399 \mathrm{~kg} / \mathrm{cm}^{2}$, Perlakuan V = 275, $035 \mathrm{~kg} / \mathrm{cm}^{2}$.

b.Perlakuan II ( $65 \%$ Kerikil + $34 \%$ pasir + 1 $\%$ tempurung kenari), menghasilkan kuat tekan $=237,344 \mathrm{~kg} / \mathrm{cm}^{2}$ lebih rendah dari perlakuan I sebagai pembanding namun 
menunjukan bahwa kuat tekan yang dihasilkan lebih besar dari mutu rancangan K 175.

2.Berdasarkan hasil pengujian kuat tekan yang diperoleh yaitu perlakuan III (64\% Kerikil $+34 \%$ Pasir $+2 \%$ Tempurung Kenari) , perlakuan IV (63\% Kerikil + 34\% Pasir + 3\% Tempurung Kenari) dan perlakuan V (62\% Kerikil + 34\% Pasir + 4\% Tempurung Kenari) menghasilkan kuat tekan yeng lebih besar dari perlakuan I dan Perlakuan II. Dengan demikian dapat disimpulkan bahwa tempurung kenari layak digunakan sebagai bahan tambahan campuran beton karena memberikan pengaruh yang cukup berarti terhadap kakuatan tekan beton.

\section{DAFTAR PUSTAKA}

Anonim, 1989, Metode Pengujian Kuat Beton. Departemen Pekerjaan Umum. LPMB, Bandung.
Koda H. A. 1997. Kajian Ekonomi Eksploitasi kenari (Canarium sp) oleh rumah tangga petani Kab. Dati II Alor. Skripsi FAPERTA UNDANA Kupang.

Koda H. A. 2004. Budidaya Tanaman Kenari (Canarium,Sp) dan penanganan pasca panen.

Lawrence, G. 1951. Taxonomy of vascular Plants..The macmilian compani New York.

Soemargono, 1974. Pengetahuan Tentang Bahan Bangunan, Rapi. Bandung.

Suryowinoto, S. 1998. Teknologi Benih.. Raja Grafinda Persada. Jakarta.

Soetjipto \& Ismoyo Prawiroharjo. 1978. Konstruksi Beton 1. Departemen Pendidikan dan Kebudayaan, Jakarta.

Val- Kol. 1982. Ensiklopedia 3 ichtiar baru Han-hoeve. Jakarta.

Wiratman wangsadinata, 1971. Peraturan Beton Bertulang Indonesia 1971N.I.-2. Jakarta. 